\title{
PRESENCIA DE Lactobacillus EN HECES DE NIÑOS LACTANTES
}

\author{
Rocío Dávalos ${ }^{1}$ \\ Paula Vergaray ${ }^{1}$ \\ Yuliana Cevallos ${ }^{1}$ \\ Tomás Agurto ${ }^{1}$ \\ Alcides Guerra ${ }^{1}$
}

\section{RESUMEN}

El feto no contiene gérmenes, después del nacimiento las superficies y mucosas son colonizadas rápidamente por microorganismos. Un adulto posee una microflora entre $300 \mathrm{y}$ 400 especies y la actividad que desarrollan son benéficas para el organismo, como protección ecológica contra formas patógenas, inmunomodulación, regulación de la fisiología digestiva y proveen de vitaminas y energía al organismo. La presencia de Lactobacillus en heces de niños lactantes se consideran como uno de los componentes mas importantes de la microflora intestinal, el transcurso a niveles digestivos hacen no viables a muchas especies por la presencia de las sales biliares y proteolisis.

Se obtuvieron muestras de niños del Hospital Naval transportados en Cary Blair y los cultivos se realizaron en agar leche. Las cepas, se caracterizaron mediante coloración gram o pruebas bioquímicas en carbohidratos, De un total de 100 muestras procesadas se aislaron Lactobacillus en un $40 \%$ de casos estudiados.

Palabras Claves: Inmunomodulación, agar leche, lactante

\section{SUMMARY}

The fetus does not contain germs, after the birth the surfaces and mucosas are colonized quickly by microorganisms, an adult possesses a microflora between 300 and 400 species and the activity that develop they are beneficial for the agency, as ecological protection against pathogenic forms, inmunomodulación, regular the digestive physiology and provides of vitamins and energy. The presence of Lactobacillus in wastes of nursing children they are considered like one of the components but important of the microflora intestinal, the course to digestive levels they do not viable to many species by the presence of them you leave biliary and proteolisis.

The samples were obtained of children of the Naval Hospital transported in Cary Blair and the cultures were carried out in milk agar, study of colonies, coloring gram, biochemical tests in carbohydrates. From 100 samples processed they were isolated Lactobacillus in a $40 \%$ of cases studied.

Key words: Immunomodulation, Milk agar, nursing

\footnotetext{
${ }^{1}$ Laboratorio de Microbiología e Inmunología, Facultad de Ciencias Biológicas, Universidad Ricardo Palma; e-mail:tagurto@mail.urp.edu.pe
} 


\section{INTRODUCCIÓN}

Los Lactobacillus, son bacilos gram positivos microaerófilos, su habitad natural es la leche, ubre de mamíferos activos. Es una de las bacterias más benéficas en la salud del hombre, son productoras de ácido láctico que por su inocuidad y $\mathrm{pH}$ bajo inhiben la proliferación de otros microorganismos en la piel y anexos del cuerpo humano, el ácido es utilizado en la industria de la higiene corporal y la bacteria en derivados lácteos, yogurt, leches agrias y quesos.

Además Lactobacillus actúa en contra de las bacterias agresoras patógenas mediante la producción de sustancias antibacterianas, que la hacen una bacteria antiséptica, denominada también prebiótica, porque es un protector ecológico. También se ha reportado que tiene un efecto sobre la inmunomodulación, regulador de la fisiología digestiva y provee de vitaminas y moléculas energéticas al hospedero.

Actualmente ingresa en la industria alimentaria como preservante de alimentos cárnicos como son los embutidos y en panificación le provee de un saborizante de mejor degustación.

\section{MATERIAL Y MÉTODOS}

\section{Material}

Cincuenta muestras de hisopado rectal de niños recién nacidos, medios de cultivo: Cary blair, Agar leche, glucosa, lactosa y material accesorio de laboratorio.

\section{Método}

Con torundas e hisopos estériles se procede a hacer un limpiado o hisopado del recto de los niños recién nacidos, los cuales son introducidos en tubos pequeños que contienen el medio de transporte Cary-Blair, etiquetados y transportados al laboratorio de Microbiología (2 horas).

La siembra se procede trasladando el hisopo con la muestra a Caldo Glucosado e incubando a $37^{\circ} \mathrm{C}$ por 2 horas y luego son sembrados por el método de estrías en superficie en Agar Leche $\mathrm{pH}$ 6,6 e incubadas a $37^{\circ} \mathrm{C}$ dentro de una jarra anaeróbica.

De las colonias circulares, incoloras blancas ó cremosas se realizó la Coloración Gram observándose bacilos delgados Gram Positivos, no esporulados. Las mencionadas colonias se resembraron en tubos con Agar Leche. Las cepas obtenidas se sometieron a pruebas bioquímicas del metabolismo de carbohidratos en caldo glucosa y lactosa a diferentes temperaturas $15^{\circ}, 30^{\circ}$ y $45^{\circ} \mathrm{C}$.

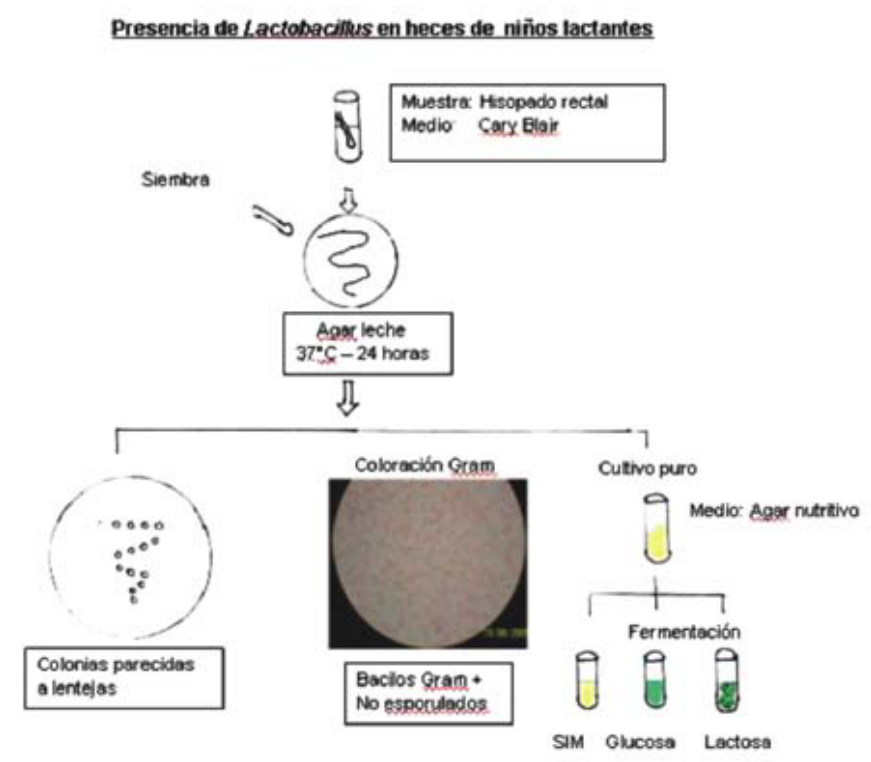




\section{RESULTADOS}

Se obtuvieron un desarrollo bacteriano en todas las muestras, aislando sólo a los bacilos Gram Positivos delgados y no esporoformas que caracteriza a Lactobacillus

En un $40 \%$ de las muestras se halló la presencia de Lactobacillus.

\section{DISCUSIÓN}

La presencia de Lactobacillus en el tracto intestinal de infantes es mayor que en adultos, la cantidad de células vivas ingeridas hasta el final del tracto intestinal disminuye hasta el $100 \%$ por la carga de bilis, otros ácidos, proteínas, la flatulencia y la carga de coliformes y otras bacterias son disminuidas por acción bactericida de Lactobacillus.

En las heces de infantes en los primeros meses de nacidos la flora microbiana es abundante en Lactobacillus equilibrados con coniformes. La digestibilidad alimentaria es favorecida por la presencia de Lactobacillus vivos que son denominados probioticos.

\section{CONCLUSIONES}

La presencia de Lactobacillus en heces de niños lactantes es positiva y altamente significativa.

\section{LITERATURA CITADA}

BOURGOIS, C. 1995 Microbiología Alimentaria n.2, v.2.Editorial Acribia

JONATHAN, E.; TEITELBAUM, W. y ALLAN W. 2002 Nutritional Impact of pre-and Probiotics as Protective Gastrointestinal Organisms Annual Review of Nutrition 22: 107-138

SNELL, E. 1989 Nutrition Research with Lactic Acid Bacteria: A Retrospective View Annual Review of Nutrition 9: $1-20$

VERSCHURE, L.; ROMBAUT, G.; SORGELOOS P.; VERSTRAETE, W. 2000 Probiotic Bacteria as Biological Control Agents in Aquaculture Microbiology and Molecular Biology Reviews 64: 655-671 